\title{
THE INFLUENCE OF CURRENT INFORMATION TECHNOLOGIES ON THE HEALTH STATUS OF SCHOOLCHILDREN
}

Sokolova Al凶, Yaskova EE

Voronezh State Pedagogical University, Voronezh, Russia

The development of information technologies, their availability for every family, the transition to distance learning could not but affect health status of schoolchildren. In the past year, amid the spread of the new coronavirus infection, the time that schoolchildren spend with gadgets has significantly increased. The relevance of this study is determined by the evaluation of the ever-increasing and, as a rule, negative impact of computer technologies on the health of schoolchildren. The study aimed to investigate the features of the effect information technologies have on the well-being of high school students and to analyze the role teachers play in popularization of healthy lifestyle and reduction of the degree of influence of information technologies on health of modern schoolchildren.

Keywords: modern information technologies, school, teacher, health of schoolchildren, lifestyle.

Author contribution: Sokolova Al — literature analysis, statistical processing, article authoring; Yaskova EE — material collection, statistical processing, literature analysis.

Compliance with ethical standards: The respondents participated voluntarily, through filling out questionnaires online. The study conformed to the biomedical ethics requirements and did not endanger the participants.

$\square$ Correspondence should be addressed: Sokolova Anastasia Igorevna

ul. Lenina, 86, Voronezh, 396043; Ya-ntares@yandex.ru

Received: 12.04.2021 Accepted: 08.05.2021 Published online: 30.06.2021

DOI: $10.24075 /$ rbh.2021.015

\section{ВЛИЯНИЕ СОВРЕМЕННЫХ ИНФОРМАЦИОННЫХ ТЕХНОЛОГИЙ НА СОСТОЯНИЕ ЗДОРОВЬЯ ШКОЛЬНИКОВ}

\section{А. И. Соколова ${ }^{凶}$, Е. Е. Яськова}

Воронежский государственный педагогический университет, Воронеж, Россия

\begin{abstract}
Развитие информационных технологий, их доступность для каждой семьи, переход на дистанционную форму обучения не могло не сказаться на состоянии здоровья обучающихся. В последний год в условиях распространения новой коронавирусной инфекции существенно возросло время, которое школьники проводят в контакте с современными гаджетами. Оценка всё возрастающего, как правило, негативного воздействия компьютерных технологий на состояние здоровья обучающихся и определяет актуальность проведённого исследования. Цель исследования заключалась в том, чтобы изучить особенности воздействия информационных технологий на самочувствие старшеклассников, а также определить роль учителя в профилактике здорового образа жизни и снижении степени влияния информационных технологий на состояние здоровья современных школьников.
\end{abstract}

Ключевые слова: современные информационные технологии, школа, учитель, здоровье школьников, образ жизни

Вклад авторов: Соколова А. И.- -анализ литературы, статистическая обработка, написание статьи; Яськова Е. Е.—сбор материала, статистическая обработка, анализ литературы.

Соблюдение этических стандартов: Данное исследование проведено на добровольной основе с использованием онлайн-сервиса. Исследование соответствовало требованиям биомедицинской этики и не подвергало опасности участников.

$\triangle$ Для корреспонденции: Соколова Анастасия Игоревна

Ул. Ленина, д. 86, г. Воронеж, 396043; Ya-ntares@yandex.ru

Поступила: 12.04.2021 Статья принята к печати: 08.05.2021 Опубликована онлайн: 30.06.2021

DOI: $10.24075 /$ rbh.2021.015

In the recent years, information technology has become an integral part of life of almost every person, especially children and adolescents leading an active lifestyle. Information technologies are all around us: at home, at school, at work, on the street, in public and private transportation, etc.; they enable the necessary communication, receipt and transmission of information, and nowadays we simply cannot refuse using them [1]. However, despite the convenience and the practical aspects, what should not be forgotten is the harm done by electronic gadgets to health, child's health in particular, when used in violation of the applicable sanitary regulations and rules.

Current computer technologies, means of transmission of information, have become an integral part of school life for both teachers and students. Interactive whiteboards, TV sets, projectors, computers, cell phones and tablets are replacing paper teaching aids; thanks to them, we can find the necessary information much faster and perform complex calculations. But does a schoolchild know how to safely use various information technologies and electronic devices? What is the extent of their negative impact on the health of this schoolchild? Large-scale adoption of electronic devices, constant use of information technology by children at home and at school affects the state of their health. Within the last 15 years, the diseases of the eyes have been on the rise among children and adolescents, which coincides with the active introduction of information technologies into.educational process [2, 3, 4, 5, 6].

Our study aimed to investigate the features of the effect information technologies have on the well-being of high school students and to analyze the role teachers play in popularization of healthy lifestyle and reduction of the degree of influence of information technologies on the health of modern schoolchildren. 


\section{MATERIALS AND METHODS}

As part of this research effort we analyzed the data obtained through surveying ninth-grade students of 102 Secondary School of the city of Voronezh. The questionnaire was designed to allow the participants to express their subjective assessment of the degree of impact of information technology on the well-being of schoolchildren. There were 15 questions and multivariate formalized answers thereto.

In total, 50 people aged 14-15 took part in the survey. We decided to select this age group because when schoolchildren turn 14-15, they start spending significantly more time with electronic devices. To ensure representativeness of the answers, the participants were not given an opportunity to discuss the questionnaire and could take as much time as they needed to fill it out.

The data obtained were processed with Statistica 13.0. The values were preliminarily assessed for conformity to the law of normal distribution of the variational series. Since distribution of the quantitative data was not different from the normal, we applied the methods of parametric statistics.

The study did not infringe on human rights, did not endanger the respondents, and met the biomedical ethics requirements. At all stages, the study conformed to the ethical standards set out in the Declaration of Helsinki and the EC Directives 8/609.

\section{RESULTS}

Introduction of the new means of communication, hardware and software into the educational process gradually made the term "computer-based learning technologies" obsolete and replaced by the concept of "information learning technologies". Information learning technologies (ILT) are a set of methods, hardware and software enabling collection, organization, storage, processing, transmission and presentation of the information that expands people's knowledge and develops their ability to manage technical and social processes [7, 8]. Information technologies play and important part in the development of various diseases in children and adolescents, although they are not the primary cause thereof. Researchers note that fewer and fewer pupils leave school healthy and the number of children suffering from various diseases is increasing [9].

A statistical analysis of the data from our survey showed that all the respondents have computers, but not all of them have a workplace with special computer furniture: $86 \%$ of schoolchildren have a table and an armchair, $10 \%$ have only a table and $4 \%$ have only an armchair (Figure 1).

Prolonged sitting at the computer causes metabolic disorders in the musculoskeletal system. Poorly selected furniture or lack thereof can have an adverse effect on the child's posture, cause painful sensations in the neck, back, wrists, all of which can trigger development of musculoskeletal system disorders in the future [10].

It should be noted that only slightly more than half of the respondents control their posture when working at a computer (56\%), the overwhelming majority (84\%) are aware of what the correct posture should be and $56 \%$ of the schoolchildren surveyed do breaks for physical exercises (on their own, without reminders from anyone else) while working with electronic devices.

The current epidemiological situation in the country and in the world can cause the development of psychoemotional disorders in children due to the forced transition to distance learning. There is a particular problem of the younger generation entering the world of information technology, this younger generation being children with fragile psyche most susceptible to destructive influences. Included in the process of growing-up, the rapidly evolving information technology plays a significant role in the development of children's memory and shaping the way they think. The stream of incoming information is ceaseless, which prevents the brain from storing it. There is also a problem of constant attention switching that can make the children unable to concentrate on anything.

SanPiN (sanitary regulations and standards) SP 2.4.3648-20 "Sanitary and Epidemiological Requirements for Organizations Rendering Fostering, Educational, Recreational Services for Children and Youth" limits use of electronic teaching aids in a lesson as follows: interactive whiteboard 20 minutes for children under 10, 30 minutes for children over 10; computer - 20 minutes for 1 st and 2 nd grade children, 25 minutes for $3 r d$ and 4 th grade children, 30 minutes for 5 th through 9th grade children, 35 minutes for 10th and 11th grade children. Extracurricular activities employing electronic devices, independent use of gadgets should also be regulated, but, unfortunately, this is rarely the case.

The results of our survey confirm that modern schoolchildren are not fully aware of the sanitary standards established for working with electronic devices. Half of the respondents believe that it is safe to spend 2-3 hours a day at a computer, $30 \%$ believe the duration of the safe period if $1-1.5$ hours and $20 \%$ of schoolchildren are convinced that it is possible to spend over 3 hours a day before the computer's display (Figure 2). The survey included a question "What is the allowed duration of a single continuous session of work at the computer?", to which $46 \%$ of the schoolchildren replied with 30 minutes, $28 \%$ believed it was 1 hour and $26 \%-2$ hours.

The computer completely captures the child's attention, who ceases to control his/her posture and loses track of

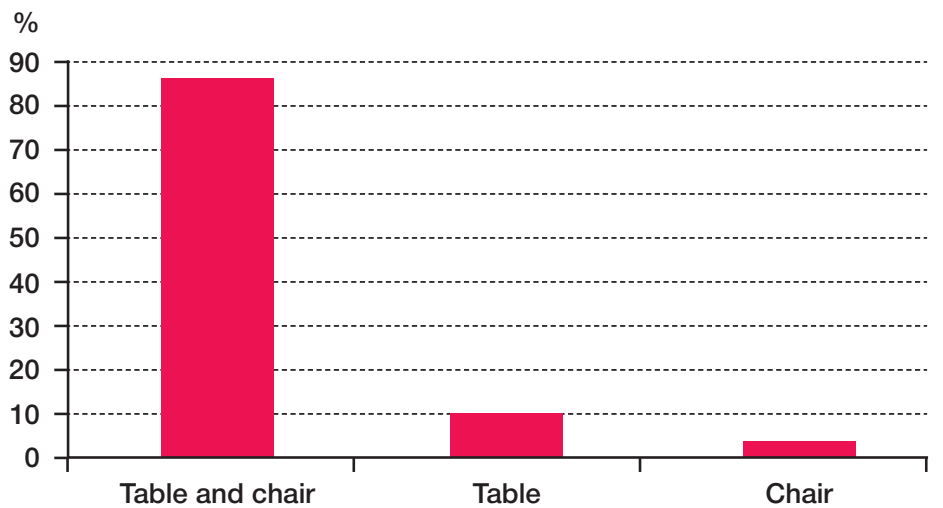

Fig. 1. Analysis of the pupils' answers to the question "Does your workplace have special furniture?" (\% of positive answers, $n=50, p \leq 0.05$ ) 


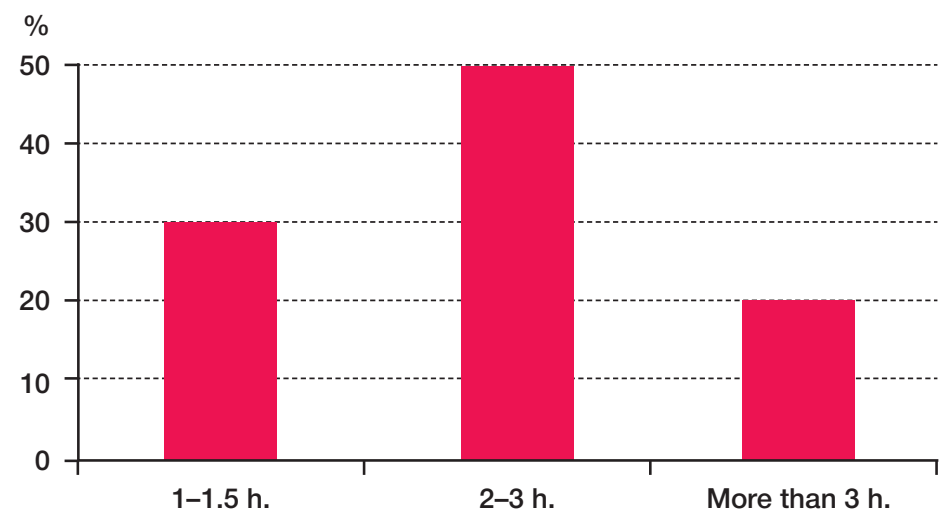

Fig. 2. Analysis of the pupils' answers to the question "How many hours a day can children of your age work at the computer?" (\% of positive answers, $n=50$, p $\leq 0.05$ )

time. Prolonged use of electronic devices and information technologies contributes to the development of rather serious pathologies in the various systems of a schoolchild's body, including the locomotor system, organs of sight, cardiovascular and nervous systems.

With the help of the questionnaire, we compared the amount of time children spent at the computer when they studied in person and after they switched to distance learning. During the in-person study period, $44 \%$ (the majority) of pupils spent 1-2 hours at the computer, $40 \%$ had 2 to 4 hours of computer time a day, $8 \%$ dedicated $5-7$ hours to the computer and $8 \%$ even more than 7 hours. Switching to distance learning marked a drastic increase of the amount of time schoolchildren sit before the computer's display: 30\% reported 5-7 hours, 30\% - 7-9 hours, 28\% stated their computer sessions lasted 2 to 4 hours and $12 \%$ confessed of $10-12$ daily hours at the computer. As a result $63 \%$ of the respondents experienced neck and back pains during the distance learning period, $41 \%$ felt dryness and pain in the eyes, $27 \%$ suffered from dizziness and headaches and $16 \%$ registered pain in their arms. In addition, 24\% of the schoolchildren that filled out the questionnaire mentioned poor appetite, 34\% noticed the quality of their sleep deteriorated and they suffered from insomnia after long hours at the computer, $12 \%$ of the respondents noticed they have put on $1-2 \mathrm{~kg}$ and $4 \%$ registered an even greater, $3-4 \mathrm{~kg}$ increase of the body weight.

\section{DISCUSSION}

The data we have obtained indicate that, to perform well academically and otherwise, schoolchildren need rationally organized workspace and electronic device/information technology use time rationing not only at school but also at home.

There is no doubt that current information technologies and electronic devices make both the learning process and the life of a pupil much more interesting and rich. After all, these technologies and devices enable learning something new on any school subject or attending training courses outside the school curriculum, going on virtual tours through museums and exhibitions, communicating with friends and making new ones regardless of where in the world they live. We find confirmation of this in the publications by researching teachers [11, 12]. It is beyond any question that today, self-development and selfeducation rely on the information technologies and electronic devices. But the most important issue in this connection is the issue of assessing the impact of these technologies on the health of a person, first of all, health of a child. This issue incorporates load rationing, workplace organization and, which is very important, self-control and self-restraint in the process of using the gadgets. A number of recent publications address the said issue. Some researchers $[13,14,15,16]$ note the state of eyes of the schoolchildren deteriorates in association with the excessive use of electronic devices, and the development of a healthy lifestyle stumbles because of the long hours of playing with gadgets.

Prolonged sitting at a computer breaks the daily routine, which adversely affects health of schoolchildren. Their nocturnal sleep time grows shorter, and, although they understand it is unhealthy, the children still stay up and before the computer late. A long stay indoors, relatively motionless, without going out into the fresh air, contributes to the development of hypodynamia, which manifests in impairments of blood circulation, respiration and other body functions; schoolchildren often complain of headaches, eye strain and feeling unwell. Improper posture, poorly selected furniture, position of the computer display, chair and table height can also harm health. Electromagnetic radiation from electronic devices also has an adverse effect on the schoolchild's health, compromising immune, endocrine and other systems. To prevent unwanted consequences in the future, parents should pay attention to the time their child spends using the phone, tablet, computer or watching TV.

Children spend a significant part of their time at school. What is the role of the teacher in reducing the risk of health problems in pupils? Undoubtedly, the teacher plays an essential part in the primary prevention of diseases, controlling, first of all, observation of the sanitary standards and school hygiene rules in the context of curricular and extracurricular activities, and secondly, actively developing and implementing various measures aimed at making the schoolchildren and their parents more knowledgeable about safe use of the information technology and electronic devices.

In our opinion, the teacher should, first of all, be the source of useful information. Schoolchildren often do not attach importance to the load they subject themselves to when using various kinds of electronic devices extensively. With their health being well, the negative consequences thereof may be a few months, or even years, delayed for them. It is the teacher who, having the knowledge, must present this information in an accessible form, with maximum efficiency, draw the schoolchildren's attention to especially important points. Such explanatory conversations can take place both in the classroom and in the course of extracurricular activities, and be regular. They will contribute to the formation of an adequate and conscious self-assessment of the pupils' behavior in the context of use of electronic devices, development of the gadget time control skill and, further on, a life routine dominated by the healthy lifestyle values. 
Taking the next step, a teacher can shape the environment that has schoolchildren busy not only during the lessons but also after them: organize various events, sightseeing tours, sports competitions, etc., involving parents to a certain extent.

Developing a system of psychological and pedagogical protection of schoolchildren from various kinds of negative effects of exposure to electronic devices, the teacher not only helps to preserve their health but also contributes to the formation of their communicative behavior and personal growth.

\section{CONCLUSIONS}

Thus, summing up the results of our research, we can state that in the recent years such work has only gained in relevance because of the widespread introduction of electronic devices and information technologies in almost all spheres of life. The impact of information technology on the health of schoolchildren can be characterized in two ways. On the one hand, it really opens up opportunities for modern pupils, enabling learning about the world around them and self-education. On the other hand, this variety of possibilities can produce positive results only if the use of electronic devices and information technology is strictly regulated factoring in age-related anatomical and physiological features of bodies of children and adolescents, as well as individual characteristics of each of them. Otherwise, the consequences for the health of pupils will be negative. What should also be underscored is the important role played by parents and teachers not only as controlling parties but also in the context of prevention of the diseases caused by the widespread penetration of information technologies into the everyday life.

\section{References}

1. Pivovarov JuP, Skoblina NA, Milushkina OJu, Markelova SV, Fedotov DM, Okol'nikov FB, Gubanov PV. Ispol'zovanie internetoprosov v ocenke osvedomljonnosti ob osnovah zdorovogo obraza zhizni. Sovremennye problemy zdravoohranenija i medicinskoj statistiki. 2020; 2: 398-413. Russian.

2. Bol'shakov AM, Krut'ko VN, Kutepov EN, Mamikonova OA, Potemkina NS, Rozenblit SI i dr. Informacionnye nagruzki kak novyj aktual'nyj razdel gigieny detej i podrostkov. Gigiena i sanitariya. 2016; 2: 172-177. Russian.

3. Libina II, Melihova EP, Popov MV. Issledovanie vliyaniya elektronnyh ustrojstv na sostoyanie zdorov'ya studentov medicinskogo vuza. Zdorov'e molodezhi: novye vyzovy i perspektivy. Psihologicheskoe zdorov'e molodezhi. Rol' informacionnyh tekhnologij. Moskva: Nauchnaya kniga, 2019; 5:181-191. Russian.

4. Popov MV, Libina II, Melihova EP. Ocenka vliyaniya gadzhetov na psihoemocional'noe sostoyanie studentov. Molodezhnyj innovacionnyj vestnik. 2019; 8(2): 676-678. Russian.

5. Stepanova MI, Aleksandrova IE, Sazanyuk ZI, Voronova BZ, Lashneva IP, SHumkova TV i dr. Gigienicheskaya reglamentaciya ispol'zovaniya elektronnyh obrazovatel'nyh resursov v sovremennoj shkole. Gigiena i sanitariya. 2015; 94(7): 64-68. Russian.

6. Milushkina OY, Skoblina NA, Markelova SV, Popov VI, Sokolova NV. The use of electronic devices by students, parents and teachers before and after the transition to distance learning. Bulletin of Russian State Medical University. 2020; 3: 77-82. Russian.

7. Aksyuhin AA, Vicen AA, Meksheneva Zh V. Informacionnye tekhnologii v obrazovanii i nauke. Sovremennye naukoyomkie tekhnologii. 2009; 11: 50-52. Russian.

8. Milushkina OJu, Eremin AL, Popov VI, Skoblina NA, Markelova SV, Sokolova NV, Tatarinchik AA. Gigienicheskaja ocenka i optimizacija uslovij truda pedagogov $v$ period provedenija distancionnogo

\section{Литература}

1. Пивоваров Ю.П., Скоблина Н.А., Милушкина О.Ю., Маркелова С.В., Федотов Д.М., Окольников Ф.Б., Губанов П.В. Использование интернет-опросов в оценке осведомлённости об основах здорового образа жизни. Современные проблемы здравоохранения и медицинской статистики. 2020; 2: 398-413.

2. Большаков А.М., Крутько В.Н., Кутепов Е.Н., Мамиконова О.А., Потемкина Н.С., Розенблит С.И. и др. Информационные нагрузки как новый актуальный раздел гигиены детей и подростков. Гигиена и санитария. 2016; 2: 172-177.

3. Либина И.И., Мелихова Е.П., Попов М.В. Исследование влияния электронных устройств на состояние здоровья студентов медицинского вуза. Здоровье молодежи: новые вызовы и перспективы. Психологическое здоровье молодежи.

Роль информационных технологий. Москва: Научная книга. 2019;5: 181-191.

4. Попов М.В., Либина И.И., Мелихова Е.П. Оценка влияния гаджетов на психоэмоциональное состояние студентов. Молодежный инновационный вестник. 2019; 8 (2): 676-678.

5. Степанова М.И., Александрова И.Э., Сазанюк З.И., Воронова Б.З., Лашнева И.П., Шумкова Т.В. и др. Гигиеническая регламентация использования электронных образовательных ресурсов в современной школе. Гигиена и санитария. 2015; 94(7): 64-68.

6. Milushkina O.Y., Skoblina N.A., Markelova S.V., Popov V.I., Sokolova N.V. The use of electronic devices by students, parents and teachers before and after the transition to distance learning. Bulletin of Russian State Medical University. 2020; 3: 77-82. 
7. Аксюхин А.А., Вицен А.А., Мекшенева Ж. В. Информационные технологии в образовании и науке. Современные наукоёмкие технологии. 2009; 11: 50-52.

8. Милушкина О.Ю., Еремин А.Л., Попов В.И., Скоблина Н.А., Маркелова С.В., Соколова Н.В., Татаринчик А.А. Гигиеническая оценка и оптимизация условий труда педагогов в период проведения дистанционного обучения. Медицина труда и промышленная экология. 2020; 60(7): 424-434.

9. Крукович Е.В. Состояние здоровья детей и определяющие его факторы. Владивосток: Медицина ДВ. 2018; 216с.

10. Милушкина О.Ю., Скоблина Н.А., Маркелова С.В., Татаринчик А.А., Мелихова Е.П., Либина И.И., Попов М.В. Влияние электронных устройств на физическое развитие современной молодежи и рекомендации по регламенту их использования. Вестник Российского государственного медицинского университета. 2019; 4: 2.

11. Альтиментова Д.Ю., Рожко К.А. Информационные технологии в образовании. Научно-методический электронный журнал «Концепт». 2016; 11: 826-830.
12. Мухлаев В.А. Использование информационных технологий в развитии познавательной активности учащихся. Образование и саморазвитие. 2014; 1: 50-55.

13. Скоблина Н.А., Милушкина О.Ю., Попов В.И., Маркелова С.В., Бокарева Н.А., Татаринчик А.А., Цамерян А.П. От традиционного к дистанционному обучению: гигиенические проблемы охраны зрения обучающихся. Гигиена и санитария. 2021;100(4): 373-379.

14. Макарова Л.П., Буйнов Л.Г., Плахов Н.Н. Гигиенические основы формирования культуры здорового образа жизни школьников. Гигиена и санитария. 2017; 5: 463-466.

15. Матюхин В.В., Шардакова Э.Ф., Ямпольская Е.Г., и др. Обоснование физиолого-эргономических мероприятий по снижению развития утомления при работе с видеодисплейными терминалами. Анализ риска здоровью. 2017; 3: 65-77.

16. Попов М. В., Либина И.И., Мелихова Е.П. Оценка влияния гаджетов на психоэмоциональное состояние студентов. Молодежный инновационный вестник. 2019; 8(2): 676-678. 